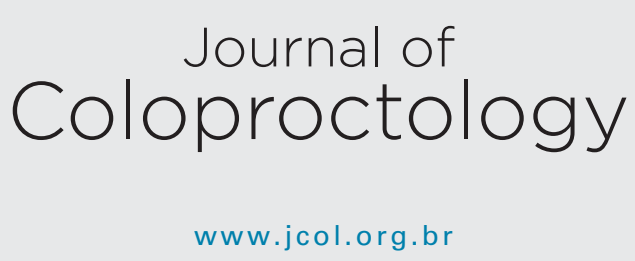

Feature Article

\title{
Current management of fistulizing perianal Crohn's disease based on serum anti-tumor necrosis factor levels and magnetic resonance imaging monitoring
}

\author{
Felipe Bernardi Wolker, Julia Gabriela Oliveira Marchiori, Eron Fabio Miranda \\ Universidade Católica do Paraná (PUCPR), Curitiba, PR, Brazil
}

\section{A R T I C L E I N F O}

Article history:

Received 28 April 2020

Accepted 7 June 2020

Available online 7 September 2020

Keywords:

Crohn's disease

Fistula

Tumor necrosis factor-alpha

Palauras-chave:

Doença de Crohn

Fístula

Fator de necrose tumoral alfa

\section{A B S T R A C T}

Perianal fistulizing Crohn's disease (PFCD) is one of the most complex challenges in the colorectal surgery nowadays, because, even with combined clinical and surgical treatment, the rate of healing of the fistulas is approximately $50 \%$. In this context, the monitoring of serum levels of anti-Tumor Necrosis Factor (anti-TNF) drugs appears as a crucial tool for the optimization of treatment, since there is a probable correlation between higher serum levels of infliximab and adalimumab with better outcomes of the disease, higher healing rates and lower recurrence rates. This review describes evidence on the use of serum anti-TNF levels and their relationship to clinical and radiological efficacy.

() 2020 Sociedade Brasileira de Coloproctologia. Published by Elsevier Editora Ltda. This is an open access article under the CC BY-NC-ND license (http://creativecommons.org/

licenses/by-nc-nd/4.0/).

Manejo atual da doença de Crohn perianal fistulizante com base nos níveis séricos de fator de necrose antitumoral e no monitoramento por ressonância magnética

R E S U M E N

A Doença de Crohn Perianal Fistulizante (DCPF) configura-se como um dos desafios mais complexos da cirurgia colorretal atualmente, isso porque, mesmo com tratamento clínico e cirúrgico combinados, a taxa de cicatrização das fistulas é de aproximadamente $50 \%$. Nesse contexto, a monitorização de níveis séricos de drogas anti-Fator de Necrose Tumoral (anti-TNF) surge como ferramenta crucial para a otimização do tratamento, uma vez há provável correlação entre maiores níveis séricos de infliximabe e adalimumabe com melhores desfechos da doença, maiores taxas de cicatrização e menores índices de recorrência.

\footnotetext{
* Corresponding author.

E-mail: eronfabiomiranda@gmail.com (E.F. Miranda).

https://doi.org/10.1016/j.jcol.2020.06.005

2237-9363/@ 2020 Sociedade Brasileira de Coloproctologia. Published by Elsevier Editora Ltda. This is an open access article under the CC BY-NC-ND license (http://creativecommons.org/licenses/by-nc-nd/4.0/).
} 
Nesta revisão são descritas evidências sobre o uso dos níveis séricos de anti-TNF e sua relação com a eficácia clínica e radiológica.

๑ 2020 Sociedade Brasileira de Coloproctologia. Publicado por Elsevier Editora Ltda. Este es un artículo Open Access bajo la licencia CC BY-NC-ND (http://creativecommons.org/ licenses/by-nc-nd/4.0/).

\section{Introduction}

Crohn's Disease (CD) is a chronic inflammatory condition of unknown etiology, which can affect any segment of the gastrointestinal tract. Due to the persistence of the inflammatory process, the disease can present itself through strictures, fistulas and perforations. ${ }^{1,2}$ Perianal manifestations are present in about $20 \%$ to $35 \%$ of patients with changes in the small intestine and large intestine. ${ }^{3}$ Perianal Fistulizing Crohn's Disease (PFCD) can affect up to $1 / 3$ of overall CD patients ${ }^{3}$ and more than $90 \%$ of patients with rectal involvement. ${ }^{4}$ Whenever present, PFCD is configured as a disease modifying element, generally linked to a worse prognosis. This is because the rates of healing of the fistula are low and recurrence is frequent, which requires greater need for immunosuppression, hospitalizations and surgeries. ${ }^{5}$ Thus, there is a great physical and psychological impact for the patients, interfering mainly in their self-image and in their sexual life.

CD related fistulas have two main components: an inflammatory (which is treated with medication) and a mechanical (treated with surgery). Among the available drugs (corticosteroids, immunosuppressants and antibiotics), it is the anti-TNF agents that achieved the best results in the treatment of PFCD. This was initially demonstrated by Present et al., who proved the efficacy of Infliximab (IFX) in closing perianal and abdominal fistulas. ${ }^{6} \mathrm{Fu}$ et al., in a meta-analysis on the treatment of PFCD with Adalimumab (ADA), demonstrated complete closure of anal fistulas in 36\% and partial response in $31 \%$ of patients. ${ }^{7}$ Combination therapy with the use of biologics and surgical manipulation of fistula path, with sepsis eradication and seton placement, currently represents the best treatment strategy for PFCD. ${ }^{8}$

More recently, evidence has shown that higher serum levels of anti-TNF agents may be associated with better results in $C D$, with higher rates of clinical remission and mucosal healing. ${ }^{9,10}$ Thus, it is speculated that in patients with PFCD there may be a benefit also in the treatment and decision making, according to the monitoring of serum anti-TNF levels, associated with the radiological control of fistulas by magnetic resonance imaging. ${ }^{11}$

\section{Therapeutic drug monitoring levels in PFCD}

In recent years, there has been growing interest between the serum concentration of drug levels and their relationship to clinical and radiological efficacy. Therapeutic Drug Monitoring (TDM) is performed based on your serum level and/or the concentration of the anti-drug antibody at a given time and can be adjusted for correct treatment. ${ }^{12}$ The determination of the anti-drug antibody is carried out in the context of an inadequate response to biological therapy. ${ }^{13}$ TDM can be superior compared to the empirical exchange of therapy, as it can be adjusted and decrease the time of an ineffective therapy, improving the treatment and its repercussions. ${ }^{14,15}$ As has already been ratified, a number of studies have demonstrated the benefits of using TDM, however there are still controversies about its real effectiveness. A prospective randomized study performed on patients with CD and ulcerative colitis, observed that after dose optimization of IFX, continued concentrationbased dosing was not superior to clinically based dosing for achieving remission after 1 year, but was associated with fewer flares during the course of treatment. ${ }^{16}$ In another prospective randomized study performed on patients with active luminal CD, D'Haens et al. concluded that increasing the dose of IFX based on the combination of symptoms, biomarkers and serum drug concentrations does not lead to corticosteroidfree clinical remission in a greater proportion of patients than increasing the dose based on symptoms alone. ${ }^{17}$

Especially in PFCD, there are data suggesting a correlation between higher serum levels of anti-TNF agents and healing of the fistula. This has been demonstrated in some cohort studies with IFX and ADA, in induction and maintenance, in adults and children with CD. ${ }^{18-23}$ Highlighted, Yarur et al., in a retrospective cross-sectional study with the largest number of patients (117), where IFX levels were analyzed for at least 24 weeks and it was found that patients with healed fistulas had higher serum levels of IFX compared to those who were not cured (15.8 vs. $4 / 4 \mu \mathrm{g} / \mathrm{mL}, \mathrm{p}<0.0001)$ and that a higher serum level of IFX at $10 \mu \mathrm{g} / \mathrm{mL}$ would be necessary for complete healing of the fistulas. The authors also noted that patients who tested positive for anti-TNF antibodies had a lower cure rate. ${ }^{20}$ Within the context of importance, it stands out the study of Strik et al., who conducted the first study with ADA in patients with PFCD. The healing of the fistulas was determined by clinical examination (absence of drainage with digital expression) and by magnetic resonance imaging (presence of fibrosis determines the closure and inactivity of the disease). Again, higher serum levels of anti-TNFs were associated with greater closure of the fistula. This study also shows the importance of magnetic resonance imaging in obtaining more objective outcomes. ${ }^{21}$

In general, patients with healed fistulas had higher serum levels of IFX and ADA compared to those with active perianal disease. This leads to speculation that the fistulizing phenotype in CD may need more active drug in circulation to control the disease, compared to the luminal phenotype. The studies published to date are associated with some limitations, such as different outcome measures, periods of analysis and lack of objective markers for fistula healing. 


\section{Magnetic resonance monitoring}

The subjectivity of the various definitions of clinical response demonstrates the need for more objective parameters in studies like these. The remission of the disease can be evaluated both clinically and by MRI, and this is a more reliable method, since fistulas classified as healing through clinical evaluation can be identified as active on MRI. The analysis of the efficacy of treatment is based on "deep remission", which characterizes the absence of the fistula path on MRI and clinical remission. ${ }^{22}$

MRI is more effective due to its high specificity and sensitivity in relation to clinical evaluation, and the van Assche score is the most used for the evaluation. The use of gadolinium contrast and T-2 sequences are the gold standard for fistula analysis, where hypersensitivity in this image indicates local inflammatory activity. ${ }^{22,23}$ Currently, in most studies, pelvic MRI scores are not standardized, and central reading remains a challenge. There are still no well-established universal criteria in pelvic MRI examinations which define closure and healing of fistulas in CD. The modified Van Assche score correlates well with clinical response, but further studies with larger sample of patients are still required for a broader validation of this method. ${ }^{23}$

\section{Conclusion}

Considering anti-TNFs as the best choice for the treatment of PFCD so far, the measurement of serum levels can be an important tool in the management of complex perianal fistulas in $\mathrm{CD}$, in association with different surgical techniques, in order to optimize the treatment of the disease, as well as the use of magnetic resonance images to confirm deep remission. Therefore, prospective studies relating the serum levels and healing rates of PFCD are expected, associated with better standardization in the form of MRI monitoring, in order to assist in the limitations that still exist in the treatment of PFCD.

Considering anti-TNFs as the best choice for the treatment of PFCD, TDM is a promising method which would place TDM as an important tool in the management of complex perianal fistulas in $C D$, in association with different surgical techniques to optimize the treatment of the disease, as well as the use of magnetic resonance images to confirm deep remission. Therefore, prospective studies relating the serum levels and healing rates of PFCD, associated with better standardization in the form of monitoring by MRI are expected, in order to assist in the limitations that still exist in the treatment of PFCD.

\section{Conflicts of interest}

The authors declare no conflicts of interest.

\section{REFERENCES}

1. Irvine EJ. Usual therapy improves perianal Crohn's disease as measured by a new disease activity index. McMaster IBD Study Group. J Clin Gastroenterol. 1995;20:27-32.
2. Satsangi J, Silverberg MS, Vermeire S, Colombel JF. The Montreal classification of inflammatory bowel disease: controversies, consensus, and implications. Gut. 2006;55:749-53.

3. Ng SC, Shi HY, Hamidi N, Underwood FE, Tang W, Benchimol EI, et al. Worldwide incidence and prevalence of inflammatory bowel disease in the 21st century: a systematic review of population-based studies. Lancet. 2018;390:2769-78.

4. Tang LY, Rawsthorne P, Bernstein CN. Are perineal and luminal fistulas associated in Crohn's disease? A population-based study. Clin Gastroenterol Hepatol. 2006;4:1130-4.

5. Tozer PJ, Burling D, Gupta A, Phillips RKS, Hart AL. Review article: medical, surgical and radiological management of perianal Crohn's fistulas. Aliment Pharmacol Ther. 2011;33:5-22.

6. Present DH, Rutgeerts P, Targan S, Hanauer SB, Mayer L, van Hogezand RA, et al. Infliximab for the treatment of fistulas in patients with Crohn's disease. N Engl J Med. 1999;340:1398-405

7. Fu YM, Chen M, Liao AJ. A meta-analysis of adalimumab for fistula in Crohn's disease. Gastroenterol Res Pract. 2017;2017:1-8.

8. Quaresma AB, Coy CSR, Damião AOMC, Kaplan GG, Kotze PG. Biological therapy penetration for inflammatory bowel disease in latin america: current status and future challenges. Arq Gastroenterol. 2019;56:318-22.

9. Maser EA, Villela R, Silverberg MS, Greenberg GR. Association of trough serum infliximab to clinical outcome after scheduled maintenance treatment for Crohn's Disease. Clin Gastroenterol Hepatol. 2006;4:1248-54.

10. Chaparro M, Guerra I, Muñoz-Linares P, Gisbert JP. Systematic review: antibodies and anti-TNF- $\alpha$ levels in inflammatory bowel disease. Aliment Pharmacol Ther. 2012;35:971-86.

11. Billiet T, Cleynen I, Ballet V, Ferrante M, Van Assche G, Gils A, et al. Prognostic factors for long-term infliximab treatment in Crohn's disease patients: a 20-year single centre experience. Aliment Pharmacol Ther. 2016;44:673-83.

12. Dreesen E, Bossuyt P, Mulleman D, Gils A, Pascual-Salcedo D. Practical recommendations for the use of therapeutic drug monitoring of biopharmaceuticals in inflammatory diseases. Clin Pharmacol. 2017;9:101-11.

13. Vermeire S, Gils A, Accossato P, Lula S, Marren A. Immunogenicity of biologics in inflammatory bowel disease. Ther Adv Gastroenterol. 2018;11, 1756283X17750355.

14. Kelly OB, Donnell SO, Stempak JM, Steinhart AH, Silverberg MS. Therapeutic drug monitoring to guide infliximab dose adjustment is associated with better endoscopic outcomes than clinical decision making alone in active inflammatory bowel disease. Inflamm Bowel Dis. 2017;23:1202-9.

15. Guidi L, Pugliese D, Tonucci TP, Berrino A, Tolusso B, Basile M, et al. Therapeutic drug monitoring is more cost-effective than a clinically based approach in the management of loss of response to infliximab in inflammatory bowel disease: an observational multicentre study. J Crohns Colitis. 2018;12:1079-88.

16. Vande Casteele N, Ferrante M, Van Assche G, et al. Trough concentrations of infliximab guide dosing for patients with inflammatory bowel disease. Gastroenterology. 2015;148:1320-9.

17. D'Haens G, Vermeire S, Lambrecht G, Baert F, Bossuyt P, Pariente $B$, et al. Increasing infliximab dose based on symptoms, biomarkers, and serum drug concentrations does not increase clinical, endoscopic, and corticosteroid-free remission in patients with active luminal Crohn's disease. Gastroenterology. 2018;154:1343-51.

18. Davidov Y, Ungar B, Bar-Yoseph H, Carter D, Haj-Natour O, Yavzori M, et al. Association of induction infliximab levels 
with clinical response in perianal Crohn's disease. J Crohns Colitis. 2017;11:549-55.

19. Yarur AJ, Kanagala V, Stein DJ, Czul F, Quintero MA, Agrawal D, et al. Higher infliximab trough levels are associated with perianal fistula healing in patients with Crohn's disease. Aliment Pharmacol Ther. 2017;45:933-40.

20. Strik AS, Löwenberg M, Buskens CJ, Gecse KB, Ponsioen CI, Bemelman WA, et al. Higher anti-TNF serum levels are associated with perianal fistula closure in Crohn's disease patients. Scand J Gastroenterol. 2019;54:453-8.

21. El-Matary W, Walters TD, Huynh HQ deBruyn J, Mack DR, Jacobson K, et al. Higher postinduction infliximab serum trough levels are associated with healing of fistulizing perianal Crohn's disease in children. Inflamm Bowel Dis. 2019;25:150-5.

22. Ruemmele FM, Rosh J, Faubion WA, Dubinsky MC, Turner D, Lazaret A, et al. Efficacy of adali- mumab for treatment of perianal fistula in children with moder- ately to severely active Crohn's disease: results from IMAgINE 1 and IMAgINE 2. J Crohns Colitis. 2018;12:1249-54.

23. Plevris N, Jenkinson PW, Arnott ID, Jones GR, Lees CW. Higher anti- tumor necrosis factor levels are associated with perianal fistula healing and fistula closure in Crohn's disease. Eur J Gastroenterol Hepatol. 2020;32:32-7. 